The University of San Francisco

USF Scholarship: a digital repository@ Gleeson Library |

Geschke Center

Sport Management

College of Arts and Sciences

2012

\title{
Smooth Operators: Recent Collective Bargaining in Major League Baseball
}

Daniel A. Rascher

University of San Francisco, RASCHER@USFCA.EDU

T D. DeSchriver

Follow this and additional works at: http://repository.usfca.edu/sm

Part of the Sports Management Commons

\section{Recommended Citation}

Rascher, D. A., \& DeSchriver, T. D. (2012). Smooth operators: Recent collective bargaining in major league baseball. International Journal of Sport Finance, 7(2), 176-208.

This Article is brought to you for free and open access by the College of Arts and Sciences at USF Scholarship: a digital repository @ Gleeson Library | Geschke Center. It has been accepted for inclusion in Sport Management by an authorized administrator of USF Scholarship: a digital repository @

Gleeson Library | Geschke Center. For more information, please contact repository@usfca.edu. 


\title{
Smooth Operators: Recent Collective Bargaining in Major League Baseball
}

\author{
Daniel A. Rascher ${ }^{1}$ and Timothy D. DeSchriver ${ }^{2}$ \\ ${ }^{1}$ University of San Francisco \\ ${ }^{2}$ University of Delaware
}

Daniel A. Rascher is a professor and the director of academic programs for the sport management program. His research interests include sport economics, finance, business research, marketing, and valuation across multiple sports.

Timothy D. DeSchriver is an associate professor of sport management in the Alfred Lerner College of Business \& Economics. His research interests include sport finance, economics and marketing; specifically in the areas of professional sport and collegiate athletics.

\section{Abstract}

In late 2011, at a time when other leagues such as the National Football League and the National Basketball Association had engaged in work stoppages, Major League Baseball owners and the MLB Players Association harmoniously agreed on a new fiveyear collective bargaining agreement. This article focuses on the reasons why MLB as an industry has maintained labor peace after decades of work stoppages. The primary aspects of the new MLB CBA, such as changes to the revenue sharing system, competitive balance tax, salary arbitration, and the amateur draft are addressed. The manner in which these economic mechanisms affect areas such as competitive balance will be analyzed. Lastly, a comparison was undertaken of the collective bargaining environment in MLB versus other professional sports leagues and other non-sports industries.

Keywords: Major League Baseball, collective bargaining, revenue sharing, free agency

\section{Smooth Operators: Recent Collective Bargaining in Major League Baseball}

In November of 2011, the ownership in Major League Baseball (MLB) and the Major League Baseball Players Association (MLBPA) announced they had agreed to a new five-year collective bargaining agreement (CBA) that would run through the end of the 2016 season. The announcement of this deal was unique in several ways. First, unlike recent CBA negotiations in other North American professional sports leagues such as the National Football League (NFL), the National Basketball Association (NBA), and the National Hockey League (NHL), these appeared to be rather harmonious. There was no war of words in the media between the two sides and the deal was struck before the end of the existing CBA. 
Second, the threat of a work stoppage never appeared to be a possibility. This is in stark contrast to the other pro leagues mentioned above, which have seen recent work stoppages as a result of failed labor negotiations. For example, the NHL lost an entire season in 2004-05 due to the failure to agree on a new labor deal. More recently, the much-publicized NFL labor talks dragged on throughout the spring and summer of 2011 and resulted in lost out-of-season training activities and a delay in the opening of training camps. In the fall and winter of 2011, the NBA's season opening was delayed over two months due to a work stoppage. While a new CBA in the NBA was agreed upon after lengthy negotiations and bickering in the press, the season had to be shortened from 82 to 66 games with those games being played in a condensed 124-day period.

Third, the MLB labor negotiations were unique in their failure to attract media attention. The negotiations of other leagues seemed to dominate the popular press in recent years. The MLB deal was done with almost no controversy, negative statements, or in-fighting. Labor harmony appears to be omnipresent in MLB. Not only is this distinct from the other North American professional leagues, but it is a major deviation from the history of the relationship between team owners and the MLBPA. Between 1972 and 1994, no MLB collective bargaining agreement was made without some type of work stoppage, whether it was an owner lockout or player strike. While not all of these stoppages affected the regular season, all of them led to some delay in team activities such as training camp. Table 1 below shows the nature and extent of MLB's work stoppages.

Table 1: History of Work Stoppages in Major League Baseball

\begin{tabular}{lccc}
\hline Year & Nature & Length (Days) & Regular Season Games Lost \\
\hline 1972 & Strike & 14 & 86 \\
1973 & Lockout & 12 & 0 \\
1976 & Lockout & 17 & 0 \\
1980 & Strike & 8 & 0 \\
1981 & Strike & 50 & 712 \\
1985 & Strike & 2 & 0 \\
1990 & Lockout & 32 & 0 \\
$1994-1995$ & Strike & 232 & 938 \\
\hline
\end{tabular}

Source: Zimbalist (2003b).

It appears that team owners and the MLBPA learned a valuable lesson from their last work stoppage that occurred in 1994-95 and led to the first cancellation of the World Series in over a century. The cancellation of the Series and subsequent delay to the start of the 1995 season did significant short-term damage to MLB. The 1995 season saw a decrease in attendance and TV ratings. The relationship between work stoppages and spectator demand is somewhat unclear based on the current body of knowledge, as will be discussed later in the article. But for MLB in the post-World Series cancellation world of the mid-1990s, it took, in part, the 1998 home run chase of Mark McGwire and Sammy Sosa to bring fans back to the ballparks. It appears that the MLB owners 
and players have learned a valuable lesson from that work stoppage and do not wish to repeat it.

The purpose of this paper is to analyze the newest CBA that was agreed on in 2011 between the MLB owners and MLBPA. Special attention will also be given to the changes in the economic system in MLB that will occur as a result of the new deal, along with a comparison of the new deal with the prior agreement that had been in place. In addition, the new CBA will be compared to the most recent labor agreements that have been made by the three other major North American professional sports leagues: the NFL, NBA, and NHL. Further, collective bargaining in MLB will be compared with typical union negotiations in non-sports industries in North America. Lastly, an analysis will be undertaken of which side-players or owners-appears to have set themselves up for future success as a result of this deal. To provide context, the article begins with a description of the history of unionization in MLB and a discussion of past CBA negotiations between the MLBPA and team owners.

\section{History of MLB Unionization}

Major League Baseball has the longest history of collective bargaining in professional sports. A great deal of content in this section has been adapted from Staudohar (2000) and Zimbalist (2003b). The unionization of professional baseball players can be traced to 1885 when the Brotherhood of Professional Base Ball Players was formed. This union, along with many subsequent organizations such as the Players' Protective Association, the Fraternity of Professional Baseball Players of America, and the American Baseball Guild, eventually failed, but they served as the groundwork for future players unions. The primary economic topics of interest for these early unions were the reserve clause that contractually tied players to their team for the entirety of their playing career, the funding of player pensions, and insurance issues. None of these organizations were successful in ending the reserve clause that contractually tied players to a single team for the entirety of their careers, and only modest gains were made in player pensions and insurance ("History," 2012).

The current players union, the Major League Baseball Players Association (MLBPA), was formed in 1954 with a player, Bob Feller, serving as the first union president. As with earlier players unions, most CBA negotiations in the 1950s and early 1960s dealt with relatively minor issues, such as those mentioned earlier, along with topics such as playing field/ballpark conditions and per diem allowances for traveling teams. The union was strongly influenced by the team owners and relatively ineffective and powerless until 1966 (Staudohar, 2000). For example, in the early 1960s, the MLBPA's legal counsel, Judge Robert Cannon, was in support of the reserve clause that greatly limited player rights, and had career aspirations to be the commissioner of MLB (Zimbalist, 2003 b). However, the bargaining strategy and goals of the MLBPA changed dramatically in 1966 with the hiring of Marvin Miller as its executive director.

In hindsight, it is interesting to note that Miller was not even the MLBPA's first choice for the job. Some players did not feel that Miller was the proper selection because he had no background in baseball. But unlike prior union chiefs, Miller had a wealth of experience in the unionization and organization of workers. He had previously been an economist with the United Steelworkers of America (Staudohar, 2000). 
Miller's negotiating style was different from that of early union leaders. His predecessors had a much more cooperative style in dealing with the owners. Miller used a more traditional approach toward labor negotiations that was common in other nonsport industries. His belief was that confrontation and conflict were the only methods that would be successful for the MLBPA to achieve its goals, with the elimination of the reserve clause being the primary goal (Staudohar, 2000). The importance of the reserve clause to the owners is noted by Krautmann, von Allmen, and Berri (2009), who found that the average apprentice, a player under the reserve clause without access to arbitration, was paid about $19 \%$ of the marginal revenue product (MRP) that he produced. The model assumed that free agents were paid $100 \%$ of their MRP. In fact, this is the lowest pay as a percentage of MRP across MLB, the NBA, and the NFL, according to Krautmann et al. (2009).

The owners did not perhaps fully understand the effect that Miller would have on the business of MLB until 1968, the first year in which Miller represented the players in CBA negotiations. In 1968, a two-year deal was reached with the most significant facet of the agreement being an increase in the minimum player salary from $\$ 6,000$ to $\$ 10,000$. While this gain may seem small by today's standards, this was a major step for many players who had not seen the minimum salary rise for over a decade; let alone a $67 \%$ increase (Staudohar, 2000). Table 2 provides data on the growth of the minimum and average player salaries over the last 40 years.

Table 2: Progression of Minimum and Average Player Salaries in Major League Baseball

\begin{tabular}{lcc}
\hline Year & Minimum Salary $(\$)$ & Average Salary $(\$)$ \\
\hline 1970 & 12,000 & 29,303 \\
1975 & 16,000 & 44,676 \\
1980 & 30,000 & 143,756 \\
1985 & 60,000 & 371,571 \\
1990 & 100,000 & 578,930 \\
1995 & 109,000 & $1,071,029$ \\
2000 & 200,000 & $1,998,034$ \\
2002 & 300,000 & $2,383,235$ \\
2005 & 316,000 & $2,632,655$ \\
2006 & 327,000 & $2,866,544$ \\
2007 & 380,000 & $2,699,292$ \\
2008 & 390,000 & $3,154,845$ \\
2009 & 400,000 & $3,240,206$ \\
2010 & 414,000 & $3,297,828$ \\
2011 & 480,000 & $3,305,393$ \\
\hline
\end{tabular}

Source: http://www.baseball-reference.com/bullpen/Minimum_salary

The 1970s was a decade that saw the MLBPA make its most significant gains at the bargaining table. The three most important changes to the economic system in MLB were the establishment of a grievance arbitration panel, the institution of free agency, and the start of salary arbitration. The 1970 CBA established a three-member griev- 
ance arbitration panel that handled disagreements between the two sides; historically, the commissioner was the final arbitrator on all decisions, and he tended to side with the owners in almost every instance. The establishment of the grievance panel had significant future ramifications. For example, in 1974, Jim "Catfish" Hunter of the Oakland Athletics had a conflict with team owner Charles Finley over payments that were to be made by the team into an insurance policy for Hunter; those payments were never made by Finley. The case was sent to the grievance panel, which ruled in Hunter's favor and declared him a free agent, thus making him the first free agent in modern MLB (Staudohar, 2000).

A year later, Andy Messersmith and Dave McNally were also ruled free agents after they challenged the reserve clause. Both men played the previous season without a contract and thus stated that they should be free to negotiate with any team because one interpretation of the reserve clause was that a player had to play one year without a contract. The grievance panel ruled in the players' favor, and this led to full free agency being agreed upon as part of the 1976 CBA. That agreement stipulated that players with six or more years of MLB experience had the right to unrestricted free agency, with some compensation to the team losing the player, upon expiration of their contract (Zimbalist, 2003b). Despite the plethora of changes that have occurred in the CBA over the past four decades, the six-year waiting period for free agency has never been altered and is still in existence today. Hakes and Turner (2011) showed that the biggest impact on player pay is free agency, but high-quality players without free agency rights also have the ability to reach into the future and obtain some of the higher pay associated with free agency by signing multi-year contracts.

Another important gain made by players at the bargaining table occurred in 1973 with the adoption of salary arbitration. The 1974 season was the first in which players had the right to file for binding salary arbitration. If a player and owner could not agree on a contract, the case could be heard by an impartial arbitrator. The arbitrator would rule on the appropriate salary for the player in the upcoming season. All contracts decided upon through arbitration were one year in length. The arbitration process was final-offer, such that the arbitrator was forced to select the salary offer given by either the player or the owner, with no compromise. Since 1990, players with three to five years of MLB experience and the top 17\% of players with two years of experience, had the ability to file for salary arbitration if they could not agree on a contract with their team (Staudohar, 2000). The new CBA that goes into effect for the 2012 season allows for the top $20 \%$ of players with two years of experience to be eligible for arbitration ("Summary," 2011). Table 3 provides a summary of the CBA highlights from 1973 to 2012.

Another aspect of CBA negotiations in the 1970s was the prevalence of work stoppages. For example, in 1972 the season was delayed 10 days and 86 games were lost due to a player strike. Four years later, the team owners locked players out of spring training camp for 17 days when the two sides failed to agree on a new deal. This was an occurrence that would be repeated over the next two decades (Zimbalist, 2003b).

The 1980s saw more tumultuous CBA negotiations between the team owners and MLBPA. In 1981, a lengthy player strike lasted 50 days and 712 games were lost. The 1981 season became known as the split season because the strike occurred in the middle of the season; from June 12 until August 1. The central issue of conflict was the 
Recent Collective Bargaining in Major League Baseball

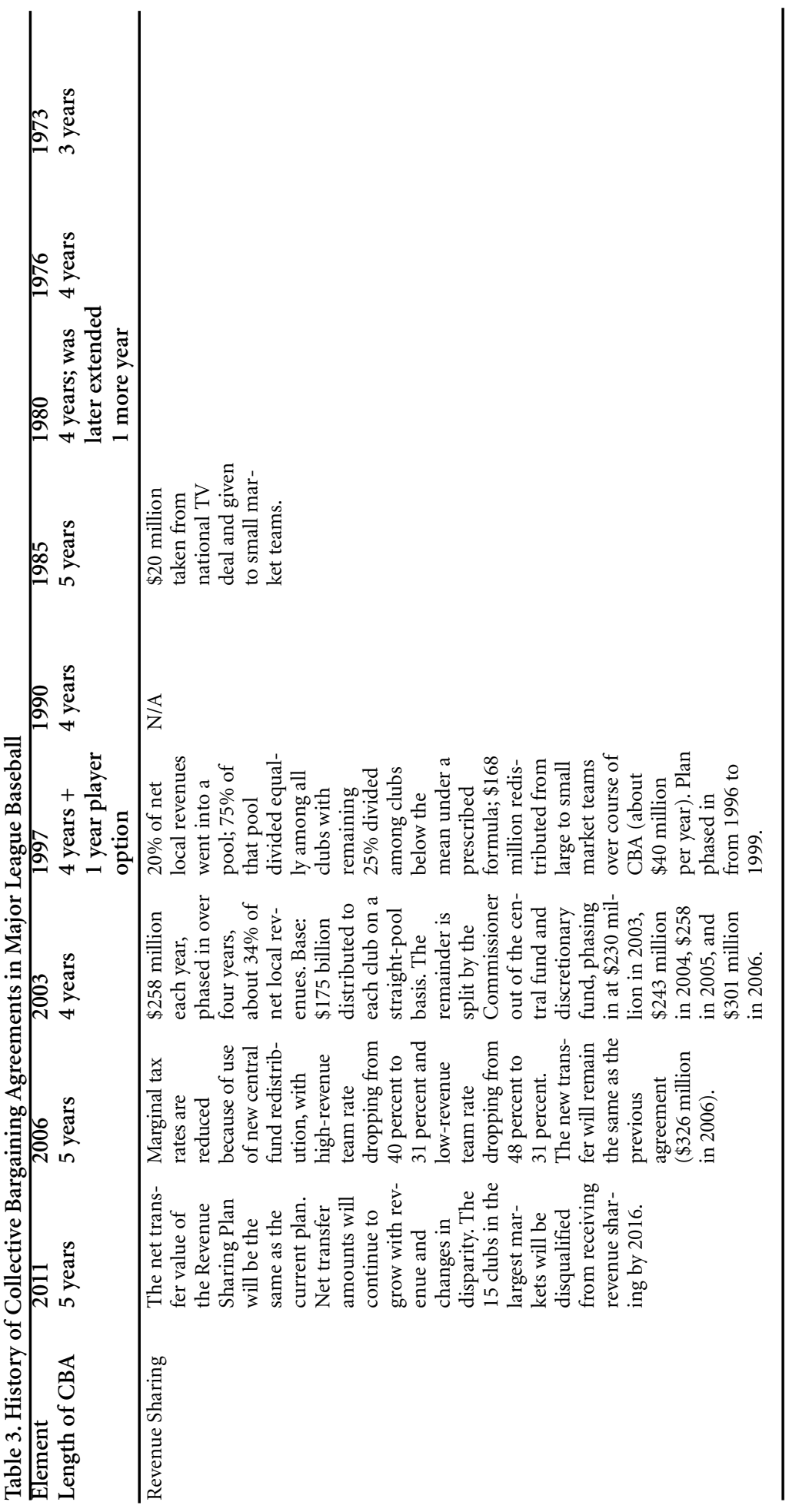




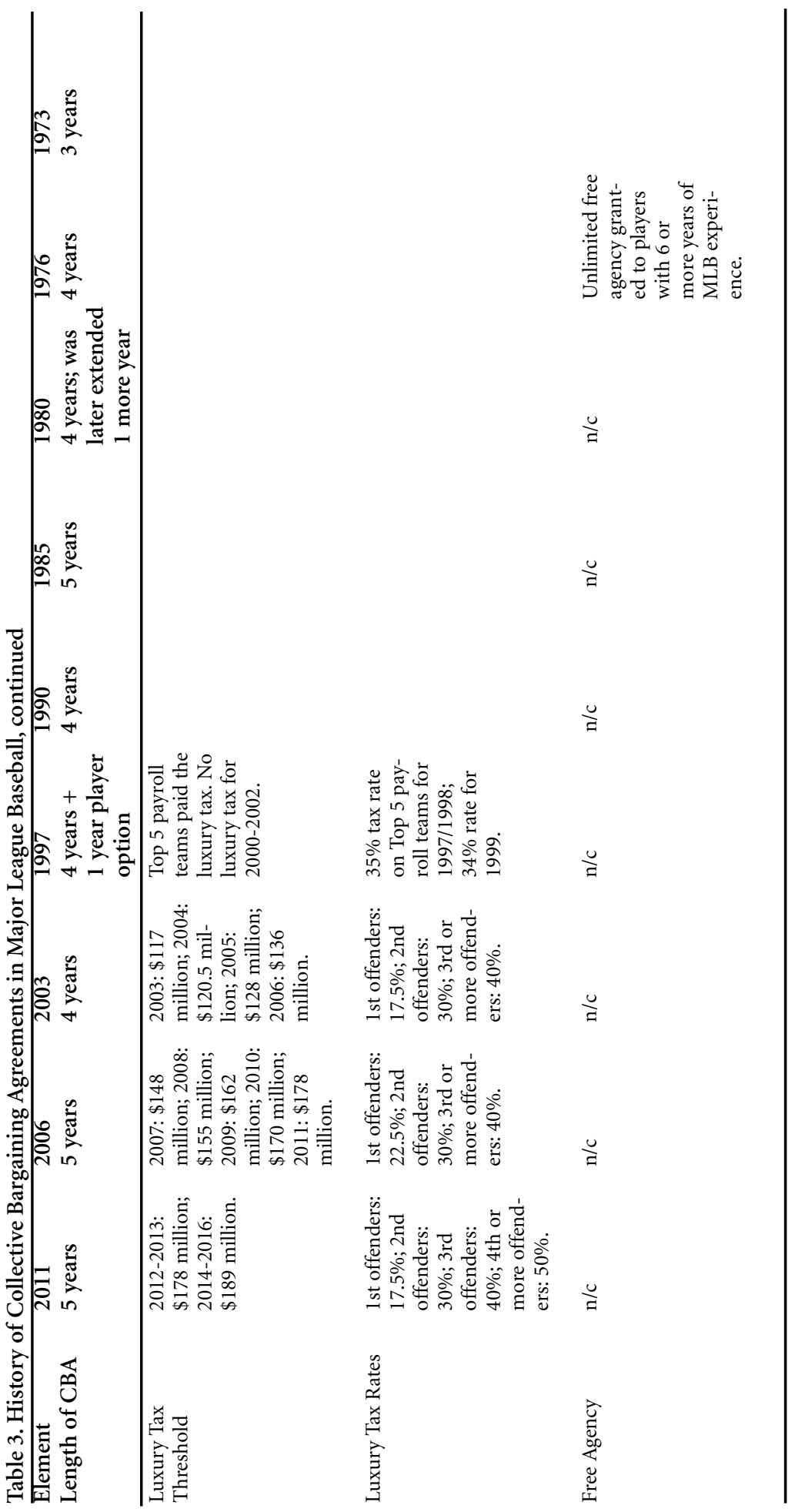

182 Volume $7 \cdot$ Number $2 \cdot 2012 \cdot$ IJSF 


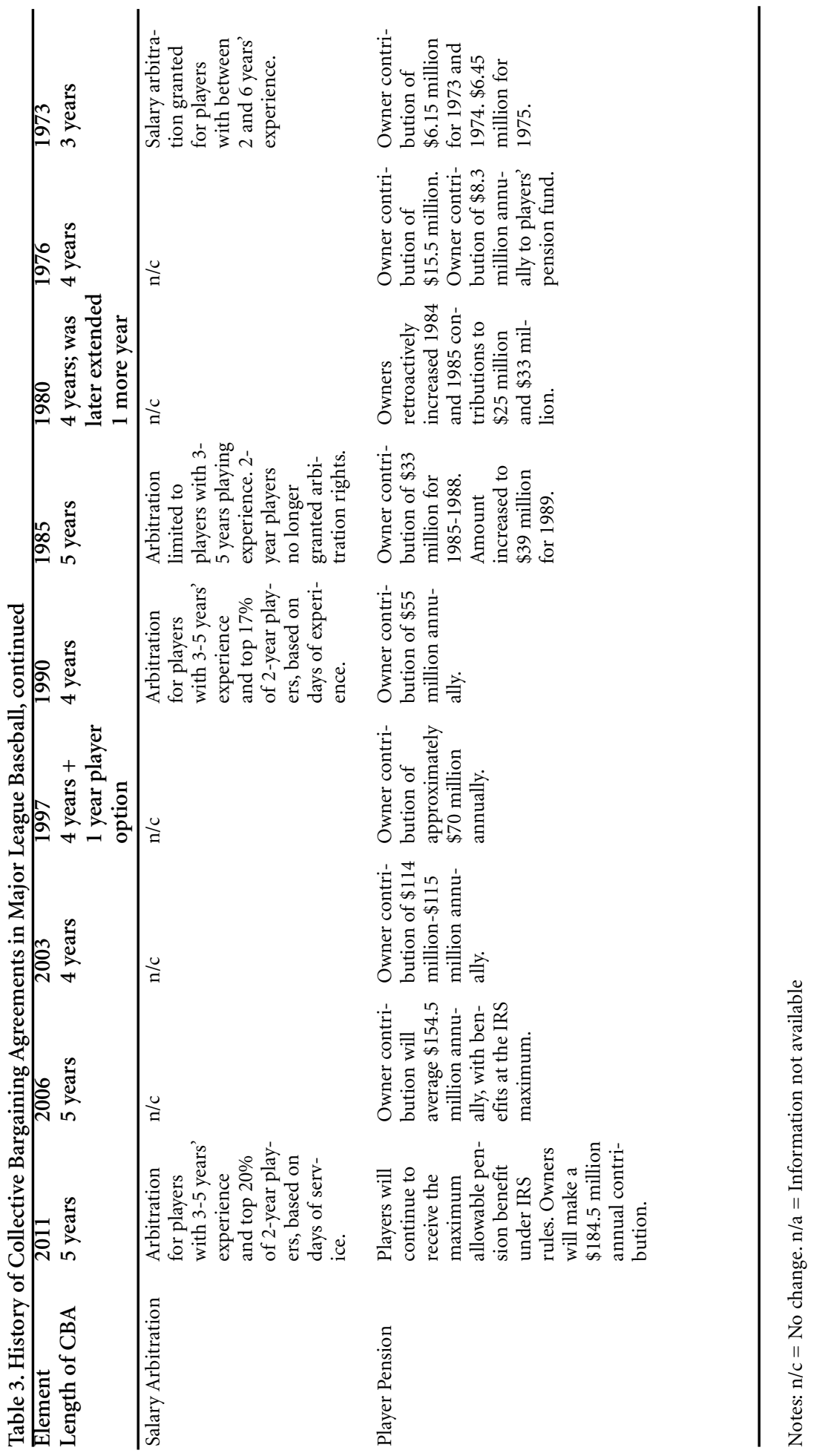


amount of compensation a team received if it lost a free agent. The owners wanted to increase the compensation, while the players believed that increased compensation would deter teams from signing free agents and, in turn, keep salaries low. A new deal was eventually signed with the owners making small gains in compensation for lost free agents. But the strike angered some fans as evidenced by decreases in both attendance and television ratings. However, both bounced back fairly quickly in 1982. But both sides suffered financially from the work stoppage. It was estimated that the owners lost a combined $\$ 72$ million in revenues and the players lost about $\$ 34$ million in wages (Zimbalist, 2003b).

Another facet of those negotiations was the volatile relationship between Marvin Miller and the owners' chief negotiator, Ray Grebey. Both men had reputations as tough negotiators, Grebey with the General Electric Company and Miller with the MLBPA and United Steelworkers of America. To say the two men did not like each other would be an understatement. Instead of negotiating, both men spent a large amount of time airing their differences in the media. This hindered advancement of the negotiations. In 1982, Miller announced his retirement as the MLBPA Executive Director. After having Ken Moffett serve in that role for a short period of time, the MLBPA selected Donald Fehr to lead it. Fehr, who held that role until 2009, was much like Miller in his negotiating style and philosophy. He believed in a confrontational style and had very little, if any, trust in the team owners. In short, similar to his predecessor Miller, he often viewed the owners as an adversary, not a partner (Staudohar, 2000).

Fehr's first round of CBA negotiations began in 1984. By then, long-time commissioner Bowie Kuhn had been replaced by Peter Ueberroth. Negotiations began about two months before the expiration of the CBA on December 31, 1984. A unique aspect of this round of negotiations occurred in February 1985, when, after pleading financial hardship, the owners were forced by the National Labor Relations Board (NLRB) to open their books to the MLBPA; this had not occurred in prior negotiations. The primary area of negotiation dealt with the funding of the players' pension by the owners. Traditionally, one-third of the revenue from the MLB's national TV contract went into the pension fund. However, as the revenues from TV grew in the 1980s, the owners believed that the amount going into the pension fund was too high (Staudohar, 2000). A conflict arose as the owners' accounting firm, Ernst \& Whitney, concluded that the owners had an operating loss of \$42 million in 1984 and projected a $\$ 58$ million loss for 1985. Simultaneously, Stanford economist Roger Noll was hired by the MLBPA, and he reported that the owners had operated at a $\$ 9$ million profit level in 1984 (Zimbalist, 2003b). Thus, the two sides could not even agree on the level of profits/losses that were occurring in the game.

By August 1985, no agreement had yet been reached and the players initiated a strike. The walkout only lasted two days, and both sides quickly agreed on a new CBA. The agreement made minor changes to the pension funding, but the larger issue that was agreed upon was the initiation of a revenue sharing plan among owners. Traditionally, all revenue from the national TV deals was split equally among all teams. The 1985 agreement took \$20 million annually from the TV contract and used it to financially aid small-market teams. This opened the door for greater future revenue 
sharing and greatly changed the way in which revenues are shared among MLB teams (Staudohar, 2000). This deal was in existence until 1990.

In 1990, the owners planned to win major concessions from the MLBPA at the bargaining table. This stance was most likely affected by the players' being awarded $\$ 280$ million in damages from the owners due to the 1987 collusion case. In that case, the MLBPA proved that the owners had colluded in the off-seasons of 1985 and 1986 to reduce the signing of free agents in an effort to curb the growth of player salaries. Evidence of this was that 29 of the 33 free agents in 1985 returned to their original teams in 1986 and the salaries for free agents grew by only five percent; a much smaller increase than in previous years without collusion. While the case was settled, the long-term damage from it lasted for years. The distrust from players toward owners was heightened as a result of the collusion case and it adversely affected future CBA negotiations (Zimbalist, 2003b).

Within the 1990 CBA negotiations, the owners sought a hard salary cap that would be equal to $48 \%$ of the total ticket sales and media revenues. The owners also pushed for a "pay to play" salary model for players with less than six years of experience as an alternative to salary arbitration. Under this model, a player's salary would be based on previous on-field performance. The players were seeking a doubling of the minimum salary along with extending salary arbitration to all players with two years of MLB experience. This time, the owners acted first by locking the players out of spring training. The lockout lasted 32 days before an agreement was reached. The owners dropped all of their primary demands and the players agreed to small changes in the salary arbitration system. The number of players eligible for arbitration increased to $17 \%$ of the players with two years of experience, sorted by experience, but not yet three years of experience. The roster size was also increased from 24 to 25, a win for the MLBPA. There were no changes to pension funding or free agency, and the minimum salary increased to $\$ 100,000$ (Zimbalist, 2003b).

The CBA negotiations that were most contentious and perhaps received the most media and public attention occurred from 1993 to 1995. These infamous negotiations resulted in the cancellation of the 1994 World Series and a delay in the start of the 1995 season. Negotiations began in early 1993 when the owners voted 15-13 to reopen the existing CBA early. However, little progress was made in negotiations throughout 1993 and the deal was to expire on December 3 of that year. The owners were pushing hard for a salary cap to curb the growth of players' salaries. Their chief negotiator, Dick Ravitch, proposed a system that included both a salary cap and increased revenue sharing to aid small-market teams and increase competitive balance. The MLBPA chief, Donald Fehr, strongly opposed any system that would limit the amount an owner could spend on player salaries but indicated that he would be open to discussion of the issue if the owners opened their financial books and agreed to share more revenue. However, Ravitch had a major problem; he could not obtain an agreement among his owners on the issue of revenue sharing. Several big-market owners were against sharing their revenue with the smaller, poorer teams. This led to a great deal of confusion and a lack of unity on the side of ownership (Zimbalist, 2003b).

As stated earlier, little progress between the owners and MLBPA occurred from January to July of 1993. Fehr started to believe that the owners' talk of revenue sharing was a delaying tactic since most of the owners' network television revenue came at 
the end of the season, after the World Series. Fehr believed that the owners were stalling. By doing this, the owners would have the ability to declare a bargaining impasse at the end of the 1993 season. Once an impasse was declared, the owners could then unilaterally impose their last offer as the CBA for the 1994 season. In hindsight, Fehr was probably correct on his views of owner behavior. The first substantive proposal by the owners to the MLBPA was not made until June 1994. It included a salary cap based on a 50/50 split of revenues. At that time, the players' salaries accounted for about $56 \%$ of revenues, so a 50/50 split would cut greatly into player salaries. In addition, no team could spend more than $110 \%$ of the salary cap figure while no team could also spend less than $84 \%$ of that amount. Under the owners' proposal, the cap was to be phased in over a four-year time period.

The owners also asked for the elimination of salary arbitration in exchange for players becoming free agents after four years of service. Lastly, the owners called for a 50/50 split of player licensing revenue; previously, the players kept $100 \%$ of this money. The players proposed no changes to the licensing revenue system, maintenance of the salary arbitration system that was in place, and a general desire to keep the status quo from the previous agreement. Donald Fehr stated that owners' proposals would cost the players about $\$ 1.5$ billion in lost wages and benefits over the deal's seven years. Similar to past negotiations, both sides worked hard to win public and media support for their side of the argument (Zimbalist, 2003b).

With no agreement in sight, on July 28, 1994, the MLBPA set a strike date of August 12. The owners responded by refusing to make a scheduled payment into the players' pension fund. The players' response to this was to file an unfair labor practices suit. The MLBPA went through with their threat and walked away from the ballparks in August. After one month of the strike and with no end in the foreseeable future, new MLB commissioner and Milwaukee Brewers owner Bud Selig cancelled the remainder of the season, including the World Series, on September 14, 1994. It had been over a century since no World Series had been played. The stalemate continued through the fall of 1994. The situation became so dire that President Bill Clinton appointed a mediator, William Usery, to the case. But Usery had little luck in forging an agreement and in December 1994, the owners announced a bargaining impasse. Their plan was to unilaterally impose the salary cap for the 1995 season. In response, the MLBPA filed another unfair labor practices suit claiming that the talks were ongoing and no impasse had occurred. By January 1995, the owners announced that they were prepared to start the season with non-union players (Zimbalist, 2003b).

A break in the situation occurred in late March 1995, when the NLRB voted 3-2 in favor of the MLBPA on their claim of unfair labor practices and the owners were not permitted to invoke their new labor system for the 1995 season. Five days after that ruling, it was upheld on appeal in the New York federal court of appeals. The judge, current U.S. Supreme Court Justice Sonia Sotomayor, issued an injunction that forced the owners to restore all the terms of the previous CBA. At that point, the exhibition season had already begun with non-union players. The owners decided that it was too risky to lock out the players and they went back to the ballparks under the previous CBA. These events also kick-started negotiations between the two sides. The negotiations went on during the 1995 season and eventually resulted in an agreement on a new CBA in November 1995; though ratification of the CBA did not occur until the 
Table 4: Revenue Sharing Amounts, by Team, for 2002-2003

\begin{tabular}{|c|c|c|}
\hline Team & 2003 & 2002 \\
\hline Montreal & $\$ 29,517,000$ & $\$ 28,493,994$ \\
\hline Florida & $21,030,000$ & $20,946,573$ \\
\hline Tampa Bay & $20,464,000$ & $14,724,463$ \\
\hline Kansas City & $19,042,000$ & $16,629,872$ \\
\hline Toronto & $18,735,000$ & $13,691,953$ \\
\hline Minnesota & $17,249,000$ & $12,977,421$ \\
\hline Detroit & $16,738,000$ & $11,615,688$ \\
\hline Milwaukee & $16,555,000$ & $8,502,007$ \\
\hline Pittsburgh & $13,299,000$ & $6,400,652$ \\
\hline San Diego & $13,250,000$ & $6,283,572$ \\
\hline Oakland & $11,756,000$ & $9,201,545$ \\
\hline Philadelphia & $9,013,000$ & $9,834,124$ \\
\hline Cincinnati & $6,469,000$ & $9,807,244$ \\
\hline Colorado & $2,469,000$ & $(-5,127,222)$ \\
\hline Anaheim & $1,874,000$ & $(-1,303,070)$ \\
\hline Arizona & $1,456,000$ & $(-3,255,682)$ \\
\hline Houston & $1,182,000$ & $(-4,326,392)$ \\
\hline Baltimore & 252,000 & $(-5,337,479)$ \\
\hline Cleveland & $(-4,828,000)$ & $(-10,612,923)$ \\
\hline Chicago White Sox & $(-4,833,000)$ & $(-3,823,142)$ \\
\hline Texas & $(-7,162,000)$ & $(-8,205,165)$ \\
\hline St. Louis & $(-9,202,000)$ & $(-8,385,888)$ \\
\hline Los Angeles & $(-9,490,000)$ & $(-9,278,555)$ \\
\hline Atlanta & $(-11,291,000)$ & $(-9,753,575)$ \\
\hline San Francisco & $(-12,959,000)$ & $(-9,638,790)$ \\
\hline Chicago Cubs & $(-16,731,000)$ & $(-8,280,260)$ \\
\hline NY Mets & $(-21,473,000)$ & $(-17,366,067)$ \\
\hline Seattle & $(-31,023,000)$ & $(-19,877,788)$ \\
\hline Boston & $(-38,692,000)$ & $(-17,896,820)$ \\
\hline NY Yankees & $(-52,650,000)$ & $(-26,640,289)$ \\
\hline Total Transfer & $\$ 220,350,000$ & $\$ 169,109,108$ \\
\hline
\end{tabular}

Note: Amounts in parentheses are revenue payers, all other amounts are revenue receivers.

Table 5: Selected Rvenue Sharing Amounts, by Year

\begin{tabular}{lc}
\hline Year & Revenue Sharing Amounts \\
1996 & $\$ 50$ million \\
2002 & $\$ 169$ million \\
2003 & $\$ 220$ million \\
2005 & $\$ 312$ million \\
2006 & $\$ 326$ million \\
2009 & $\$ 433$ million \\
2010 & $\$ 404$ million \\
\hline
\end{tabular}


Rascher, DeSchriver

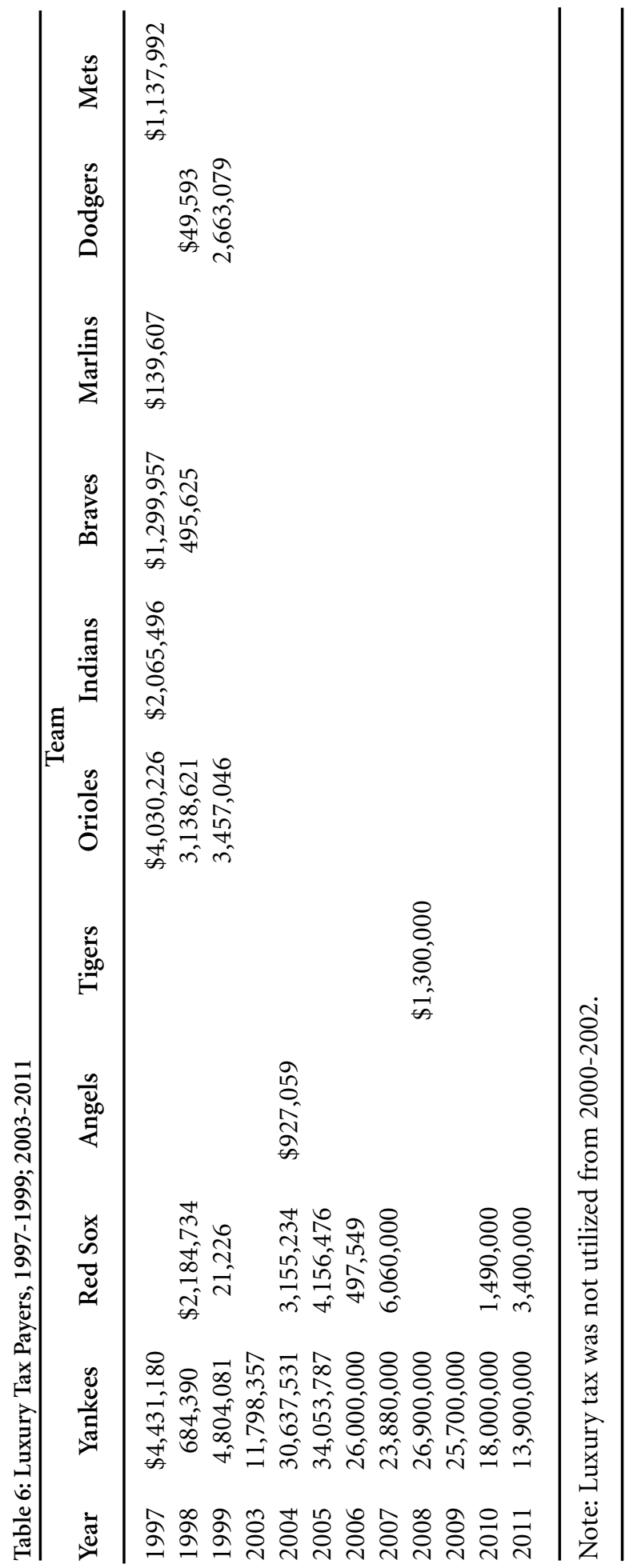

188 Volume $7 \cdot$ Number $2 \cdot 2012 \cdot$ IJSF 
spring of 1996. The new six-year agreement called for a revenue sharing system that was phased in over the length of the CBA. Each team would be taxed $20 \%$ of their net local revenue with three-quarters of the total tax money being split equally among all teams. The remaining one-quarter would be distributed to the teams with below average revenue levels. In 2001, approximately \$168 million was redistributed from largemarket to small-market teams through this revenue sharing plan (Zimbalist, 2003b).

Another important aspect of the agreement was the imposition of a competitive balance tax, commonly known as the luxury tax. Under the plan, a team would pay a tax to the league if it spent over a designated amount on player salaries. The system was first used for the 1997 season. For example, the top five payroll teams in 1997 paid a $35 \%$ tax on the amount of money they spent on salary over the midpoint of the fifth and sixth highest payroll teams. So, if a team was $\$ 10$ million over that amount, it paid a tax of $\$ 3.5$ million. The collected tax money was distributed to teams that did not pay the tax. Another outcome of the 1995 CBA was a realization that small- and largemarket owners had increasingly divergent interests. In some ways, the rift between large- and small-market owners had as much impact on the difficulty in getting a deal done as the differences between players and owners.

The fallout from the 1994-95 strike has been greatly studied in academic literature. Staudohar (2000) reported that average game attendance fell by over $20 \%$ from early 1994 to 1995 and that owners reported losses of over \$1 billion from the cancelled games. In comparison, Schmidt and Berri $(2002,2004)$ concluded that the impact was actually about a 35\% drop in attendance, but that it recovered quickly in subsequent seasons. Coates and Harrison (2005) found that the strike had about a 24\% impact on attendance, but it also recovered by the next season. The 1981 and 1972 strikes resulted in losses of about 10-12\%, and even previous work stoppages that did not result in missed regular or postseason games had negative impacts on attendance of between 3-7\% according to Coates and Harrison (2005). On the other hand, Matheson (2006) showed that once the positive impact of new stadiums was accounted for, baseball attendance from 1995 to 2003 continued to remain lower than pre-1994 levels.

The CBA negotiations that followed the lost World Series were amicable in comparison to 1995. The next round of discussions began in 2001 as the 1995 deal was nearing expiration. An important aspect of these negotiations was that they occurred shortly after the MLB owners and Selig published the findings of their Blue Ribbon panel in July 2000. The panel, comprised of 12 owners and four outside experts, was asked to study MLB's economic system and to make recommendations for improvement of the game in areas such as competitive balance. No player input was asked for with respect to the Blue Ribbon panel. The panel made several recommendations such as increased revenue sharing, a more restrictive luxury tax system, and changes to the amateur draft. In part, the panel and its findings appeared to be a strategy by the owners to set the parameters for their bargaining position going into the 2001 negotiations.

The negotiations began rather slowly, with no talks beginning until the spring of 2001. Selig's strategy appeared to be a delay in substantive talks in an effort to improve the owners' bargaining power. Selig did not attend any bargaining sessions until January 2002; two months after the previous deal expired. In November 2001, no formal offers had been made by the owners and in a surprise move right after the World Series, Selig announced, with no prior signal to the MLBPA, a plan to contract two 
teams and thus eliminate 50 Major League roster spots. Noll (2003) calculated that \$1 billion would accrue to the rest of the teams in MLB as a result of contracting the two weakest teams. He noted that the incentives to contract teams increased with more revenue sharing. Without revenue sharing, a weak team must stand on its own, but with revenue sharing the strongest clubs ultimately subsidize the weakest ones.

The owners' first formal proposal in January 2002, included many ideas presented in the Blue Ribbon panel report such as amateur draft changes; along with new ideas such as contraction, the right for a franchise to release a player if it believed the salary arbitration figure determined by the impartial arbitrator was too high, a call for highsalary teams to pay more into the pension fund than low-salary teams, and, of course, a salary cap. The MLBPA believed, and rightly so, that the owners' proposals were an attempt to reduce future player salaries. For example, a team would perhaps be less willing to increase their payroll if it must also pay more into the players' pension fund by doing so.

This initial proposal was coldly received by the MLBPA. The union believed that the owners' tough demands were nothing more than a bargaining ploy. By asking for significant changes, the owners knew that they would not get them all. If they only got a portion of these demands, the owners would be quite happy with the agreement. In the end, it turned out that the owners got almost none of their proposed changes to the CBA. In mid-August, the MLBPA set a strike date of August 30, 2002. An agreement was reached between the players and owners on the afternoon of that day; just a few hours before games were to be played. In stark contrast to $1994-95$, no strike occurred and no games were lost. It was the first time in over two decades that no work stoppage occurred as a result of stalled CBA negotiations. It appeared that both sides had learned their lesson from 1995 and did not want to suffer the financial and public relations damage from a work stoppage. These negotiations also occurred less than a year after the 9/11 tragedy, in which MLB played a very public role in helping the citizens of the United States heal. Following the burst of the technology bubble, it was also a time when the American economy was rather weak (Zimbalist, 2003b).

The new four-year agreement was similar to the prior deal with the exception of a few changes. The minimum player salary was increased $50 \%$ to $\$ 300,000$ and more revenue was shared among owners. The new plan called for $34 \%$ of net local revenues to be shared across teams. This resulted in $\$ 229$ million to $\$ 258$ million being shared annually over the course of the deal. Table 4 provides data on the amount of revenue that was paid or received by each team for 2002 and 2003, and Table 5 shows the total amount of revenue that was shared across selected years. Additionally, the players' benefit fund was increased and plans were made for the initiation of a drug testing program for steroids. Another area that was changed by the new deal was the competitive balance tax, also known as the luxury tax. Under the prior deal, the tax only affected the top five payroll teams, and it appeared that the luxury tax had little effect on salaries over the course of the deal, so it was eliminated entirely for the 2000-2002 seasons (Zimbalist, 2003b).

Under the new agreement, the rule that the top five payroll teams pay the tax was eliminated. In its place, payroll thresholds were established, and any team that surpassed the threshold level was required to pay a percentage tax on the amount of overage. The threshold was set at $\$ 117$ million for 2003 , and it escalated each year until it 
was up to $\$ 136$ million for the final year, 2006. The tax rate was $17.5 \%$ for first offenders, $30 \%$ for second offenders immediately after the first offense, and $40 \%$ thereafter for consecutive offenders (Zimbalist, 2003a). In retrospect, the luxury tax did little to curb rising team salaries. Most teams did not have the financial ability to go over the high tax thresholds and those that did, such as the New York Yankees, could afford to pay the tax. Table 6 displays the teams and amounts paid in luxury tax from 1997 to 1999 and 2003 to 2011. As stated earlier, no luxury tax system was implemented from 2000 to 2002 . After receiving a great deal of attention after Commissioner Selig's public statements on the matter, contraction was ultimately set aside. Somewhat ironically, as revenue sharing continued to increase, the incentives for contraction grew. However, to this day it still remains dormant. Covington (2003) noted that the issue of whether the owners must bargain over contraction or can act unilaterally is still undecided.

An important result of the revenue sharing plan that began in 1997 and was extended in the 2003 agreement was that it actually made competitive balance worse according to Maxcy (2009) and Zimbalist (2003a). As smaller market teams produced more revenue, they received less revenue from the sharing plan. Thus, their incentives to invest in higher revenue producing assets, like better players, was reduced, leaving them with the highest marginal tax rate within the revenue sharing system. Zimbalist (2003a) calculated that the marginal tax rate for low revenue producing teams was about $41 \%$ at the end of the 1997 agreement. It increased to about 47\% with the 2003 CBA.

Individual case studies of teams (as reported by the media; see Bloom, 2006a; Dosh, 2007; Kovacevic, 2005; Snel, 2005; Weir, 2002) found that some teams appeared to be simply pocketing the money received from revenue sharing. For example, the Pirates, Expos, and Brewers lowered their player payrolls after receiving increases in revenue sharing payments. The CBA required owners to spend the money on improving their performance on the field, but that does not mean that the teams' payrolls had to increase from the year before. Given that money in this case is fungible, owners could do what they wanted with their revenue sharing allotment. In fact, some of the smallmarket owners are notable billionaires and if they thought that investing more money in players would increase their profits or utility, they certainly could do so without relying on MLB's revenue sharing money. Therefore, it is not surprising that some revenue-sharing recipients choose to spend that money elsewhere and not on player payroll.

Interestingly, at the time neither side foresaw that the most controversial topic that was discussed in this round of negotiations was steroid use and the testing for performance-enhancing drugs (PEDs). It was a short time after this agreement was signed that PED use in MLB became a national issue when the BALCO controversy brought national media attention to players such as Barry Bonds.

In October 2006, Selig and Fehr held a press conference to announce that a new CBA had been agreed upon. At five years in length, it was the longest deal ever agreed upon by the two sides. The negotiations occurred with little public bickering and fanfare. At the time, MLB was on firm financial footing with league revenues and player salaries being at all-time highs. The U.S. economy was booming, and corporations and media outlets were spending on MLB, while attendance numbers were also increasing. In short, both sides were happy and this made for easy negotiations. A minor change was made to the luxury tax system with higher payroll thresholds going into effect; by 
2011, the threshold was $\$ 178$ million. While the old CBA had not been reopened between 2002 and 2006, the drug testing portion of it was changed, with the agreement of both sides, in the wake of the steroid scandal. Testing was increased and stiffer penalties were invoked. These provisions were extended through the 2006 deal and an agreement was reached to discuss mandatory testing for human growth hormones (Bloom, 2006b). The drug testing program was bilaterally stiffened again in 2008 by the MLBPA and owners.

\section{The New Deal and Changes From the 2006 MLB CBA}

There were several changes made to the MLB collective bargaining agreement in 2011. Three of these changes directly dealt with the nature of the game itself. First, the two sides agreed to add a second Wild Card team in both the American and National Leagues. Under the new format, each division winner along with the two teams with the best winning percentage in their league, the so-called Wild Card teams, qualify for the postseason. The two Wild Card teams will have a one-game playoff to determine who will advance to the league divisional series. The goal of this change was to increase the number of playoff games and to keep more teams in the late-season race for the playoffs. Some research has shown that fans want more playoff games and an increase in the likelihood of teams reaching the post-season. This new format may also lead to an increase in television revenues with two additional postseason games being played (O'Reilly, 2011). This should have a slight positive effect on lowering the dispersion of revenues across franchises as more teams vie for the playoffs.

Second, the new CBA also calls for an equal number of teams in both leagues. As of the 2012 season, the National League had 16 teams while the American League had 14 members. Under the new CBA, the Houston Astros will move from the NL to the AL in 2013 to create two leagues of 15. Third, along with this move, the number of intraleague games played between NL and AL teams will increase in the future and will be played throughout the season ("Summary," 2011). In the past, there have been certain segments of the season where intraleague games were played. The continuous playing of intraleague games must occur with an odd number of teams in each league.

The CBA also resulted in relatively minor changes in the revenue sharing system. Under the 2006 CBA, approximately \$325-350 million was transferred from the largerevenue clubs to small-revenue clubs. This level of revenue transfer will continue in the future, with growth in transfers coming if league revenues grow and the disparity between small and large revenue teams widens. Thirty-one percent of net local revenues will be shared, plus additional central revenues, and re-distributed based on market potential. Recipients must have payrolls that are $25 \%$ greater than the revenue sharing funds received, and they must document that the money is not spent on debt reduction, but to improve their team. This will help deter recipient teams from pocketing the money, which should improve competitive balance substantially, to the extent that this is enforceable.

One change that was made is that the new CBA states that by 2016, the 15 teams in the largest markets will be disqualified from revenue-sharing ("Summary," 2011). Thus, those teams in large markets that fail to generate the larger revenues will no longer have the ability to be revenue-sharing recipients. This rule penalizes large-market clubs that fail to generate revenues that would place them in the top half of the 
league. There is no provision allowing teams in shared markets to potentially be revenue-sharing recipients. Another provision of the new CBA was that the Commissioner's Discretionary Fund was increased from $\$ 10$ million to $\$ 15$ million. This is a pool of money that can be distributed to different clubs based on the decision of the Commissioner's office and has been traditionally given to small-market clubs ("Summary," 2011).

Another change in the new CBA was in the dollar amounts for the competitive balance (luxury) tax. The team salary threshold level of $\$ 178$ million will be unchanged for the 2012 and 2013 seasons. However, it will increase to $\$ 189$ million for the 2014, 2015, and 2016 seasons. The tax rate for first-time offenders will drop from $22.5 \%$ to $17.5 \%$, but it will increase from $40 \%$ to $50 \%$ when a team goes over the cap number for the fourth time. The rates will remain the same, 30\% and $40 \%$ for second and third offenders, respectively ("Summary," 2011). Given the MLBPA's opposition to any type of luxury tax or salary cap, this appears to be a compromise for both sides. While new offenders will pay a smaller penalty for going over the tax amount, perpetual repeat offenders such as the New York Yankees will pay a steeper price. These changes should have a minimal effect on competitive balance given that they are a relatively small deviation from the prior CBA. Moreover, the tax revenues will not go directly to smallmarket teams, but to general industry growth. The impact on competitive balance comes from taxing high-spending clubs and thus reducing their expenditures-not from re-allocating that money to small market clubs.

An adjustment was also made to the salary arbitration system. The number of twoyear players who are eligible for arbitration went from the top $17 \%$ to the top $22 \%$, based on service time ("Summary," 2011). More second-year players will now be eligible to apply for salary arbitration if they cannot agree on a new contract with their team. This may have a long-term effect of increasing player salaries since we have seen arbitration positively influence salaries over the past four decades. However, similar to the adjustment in the luxury tax, this provision is a relatively minor change from the prior CBA and may perhaps have little, if any, long-term effect on player salaries.

Another change that will directly affect player salaries is an increase in the minimum salary. The minimum salary will rise to $\$ 480,000$ in 2012, a $\$ 69,000$ increase from 2011. It will increase to $\$ 500,000$ by 2014, and cost-of-living adjustments will occur for 2015 and 2016 ("Summary," 2011). These changes will benefit the players, though they may negatively impact low-revenue teams that often have more players under the reserve clause versus large-market teams. If the new minimum salary has a greater impact on low-revenue teams, that may also then affect competitive balance across MLB.

A few minor changes were made to the free agency system as a result of the new CBA. The changes primarily deal with draft pick compensation for teams that lose players via free agency. Previously, MLB had a system in place where players were designated as Type A or Type B free agents based on performance with the amount of compensation for the team that lost the player based on that player's designation. For example, if a team lost a Type B player, it would receive an additional amateur draft pick that would occur between the first and second rounds, known as a "sandwich" pick. This system has been altered with the new CBA. Under the new deal, a team is only available for compensation if the player they lost via free agency was with their team for the entirety of the previous season. So, if a player who was in the last year of 
their contract is traded in July, which has been quite common, the team that acquires the player is not eligible for compensation if they lose the player via free agency. Additionally, a player will only be subject to compensation if his prior team made him an offer of a minimum one-year guaranteed contract with a salary equal to the average salary of the top 125 highest-paid players from the prior season. This rule takes the place of the Type $\mathrm{A} / \mathrm{B}$ free agent designations. If a player meets the requirements for compensation, the team that loses that player will still receive an additional pick between the first and second rounds of the amateur draft, as it did under the prior CBA ("Summary," 2011).

The amateur draft was amended in several other areas. The draft has been and will continue to be held annually in June. However, the deadline by which draftees must be signed by their club will be moved from August 15 to between July 12 and July 18, possibly forcing the drafted players to sign earlier and get them onto minor league rosters. One issue that has been raised in recent years has been the amount of money that teams have spent on signing bonuses for top draft picks. The numbers have grown rapidly over the past decade. In the past several years, players such as Bryce Harper, Stephen Strasburg, and Jamison Taillon have received signing bonuses in excess of $\$ 6$ million. In comparison, the top signing bonus in 1996 was about \$2 million. In response to increasing signing bonuses, the new CBA institutes a signing bonus pool system in which each team will be allocated an amount of money for the signing of all their draftees within the first 10 rounds. The amount of money that each team will be allocated for these signing bonuses will be based on the quantity and position of the team's picks. Dollar values are assigned to the draft picks and any player taken after the first 10 rounds will not count toward the signing pool amount unless the player receives a bonus in excess of $\$ 100,000$. If a team goes over their bonus pool amount by $0-5 \%$, it will pay a $75 \%$ tax on the overage. That amount increases to a $100 \%$ tax if the team is over the pool amount by $10 \%$ or more. The actual dollar amounts of the signing bonus pools were not enumerated in the CBA. Additionally, a team may also lose future draft picks if it is more than five percent over its pool amount. The money generated from the signing bonus pool will be redistributed to teams that do not exceed their bonus pool cap, and any lost draft picks will be assigned to those teams through a lottery. The lottery will be weighted toward those teams with the lowest winning percentage and/or smallest revenues in the previous season ("Summary," 2011).

Another change to the amateur draft is that teams with the lowest revenues and the smallest markets will have the opportunity to obtain additional draft picks. Historically, draft order was based on the winning percentages of the teams. The goal of this new provision is to aid the poorer teams in improving on-field quality. These additional picks should help the small-market teams put a better product on the field. Under the new system, the 10 clubs with the lowest revenues and the 10 clubs with the smallest markets will be entered into a lottery for six picks that will occur after completion of the first round. The lottery is weighted toward those teams with the lowest winning percentage in the previous season. Also, those clubs that do not obtain a pick through this lottery, along with the clubs who make payments under the revenue sharing plan, will be entered into a second lottery for six picks at the conclusion of the second round. This lottery will be weighted based on previous season winning percentage ("Summary," 2011). Again, the goal of this CBA provision is to aid small-market teams 
Table 7: Collective Bargaining Agreements Across Leagues, 2012

\begin{tabular}{|c|c|c|c|c|}
\hline CBA Component & MLB & NFL & NBA & NHL \\
\hline Length of Deal & $\begin{array}{l}5 \text { years }(2012- \\
16)\end{array}$ & $\begin{array}{l}10 \text { years }(2011- \\
2020)\end{array}$ & $\begin{array}{l}10 \text { years (2011- } \\
2020) \text {, mutual } \\
\text { opt-out after } 6 .\end{array}$ & $\begin{array}{l}5 \text { years, but } \\
\text { optioned for } 1 \\
\text { more }(2006-7 \\
\text { through } 2011- \\
12 \text { season) }\end{array}$ \\
\hline $\begin{array}{l}\text { Teams in } \\
\text { Postseason }\end{array}$ & 10 of 30 teams & 12 of 30 teams & 16 of 30 teams & 16 of 30 teams \\
\hline Revenue Sharing & $\begin{array}{l}31 \% \text { of net local } \\
\text { revenues are } \\
\text { shared plus } \\
\text { additional cen- } \\
\text { tral revenues } \\
\text { and re-distrib- } \\
\text { uted based on } \\
\text { market poten- } \\
\text { tial. Recipients } \\
\text { must have pay- } \\
\text { rolls } 25 \% \\
\text { greater than } \\
\text { revenue sharing } \\
\text { funds received. } \\
\text { Must document } \\
\text { that it's not } \\
\text { spent on debt } \\
\text { reduction, but } \\
\text { to improve } \\
\text { team. }\end{array}$ & $\begin{array}{l}\text { League national } \\
\text { revenues dis- } \\
\text { tributed evenly. } \\
\text { Portion of tick- } \\
\text { et sales shared } \\
\text { evenly. Other } \\
\text { Team revenues } \\
\text { partially redis- } \\
\text { tributed from } \\
\text { top earning } \\
\text { clubs to low } \\
\text { earning clubs } \\
\text { who meet spe- } \\
\text { cific spending } \\
\text { requirements. }\end{array}$ & $\begin{array}{l}50 \% \text { of a team's } \\
\text { revenue minus } \\
\text { certain expenses } \\
\text { will be thrown } \\
\text { into a revenue } \\
\text { sharing pot. } \\
\text { Teams with } \\
\text { most need } \\
\text { receive up to } \\
\$ 16 \text { million per } \\
\text { year. Total pot } \\
\text { should be about } \\
\$ 200 \text { million by } \\
2013-14 \text { season. }\end{array}$ & $\begin{array}{l}\text { Lower-revenue } \\
\text { and small mar- } \\
\text { ket clubs will } \\
\text { receive revenue } \\
\text { from central } \\
\text { fund and } \\
\text { directly from } 10 \\
\text { highest revenue } \\
\text { clubs }\end{array}$ \\
\hline Luxury Tax & $\begin{array}{l}\text { Payrolls over } \\
\$ 178 \text { million are } \\
\text { subject to a tax } \\
\text { that escalates } \\
\text { depending on } \\
\text { how many } \\
\text { times in a row a } \\
\text { team exceeds } \\
\text { the threshold. } \\
\text { Tax revenues go } \\
\text { to industry } \\
\text { growth initia- }\end{array}$ & $\begin{array}{l}\text { None because } \\
\text { there is a hard } \\
\text { salary cap }\end{array}$ & $\begin{array}{l}\text { Escalating luxu- } \\
\text { ry tax paid for } \\
\text { payrolls above } \\
\text { the salary cap. } \\
\text { Escalation } \\
\text { occurs based on } \\
\text { amount above } \\
\text { the cap and } \\
\text { whether team } \\
\text { continuously } \\
\text { goes above the } \\
\text { cap. }\end{array}$ & None \\
\hline
\end{tabular}


Table 7: Collective Bargaining Agreements Across Leagues, 2012, continued

\begin{tabular}{|c|c|c|c|c|}
\hline CBA Component & MLB & NFL & NBA & NHL \\
\hline $\begin{array}{l}\text { Salary Cap/ } \\
\text { Minimum }\end{array}$ & $\begin{array}{l}\text { No salary cap or } \\
\text { team minimum. } \\
\text { Players earned } \\
51 \% \text { of league } \\
\text { revenues in } \\
2007 .\end{array}$ & $\begin{array}{l}\text { Hard cap of } \\
\$ 120.375 \mathrm{M} \text { (+ } \\
\$ 22.025 \mathrm{M} \text { of } \\
\text { player benefits) } \\
\text { in 2011, grow- } \\
\text { ing annually } \\
\text { with revenues. } \\
\text { League mini- } \\
\text { mum in 2011 } \\
\text { and 2012, Team } \\
\text { minimum in } 4 \\
\text { year blocks } \\
2013-2016 \text { and } \\
2017-2020 . \\
\text { Total Player } \\
\text { Comp = 55\% of } \\
\text { projected } \\
\text { League Media } \\
\text { Revenue }+45 \% \\
\text { of projected } \\
\text { NFL Ventures } \\
\text { Revenue }+40 \% \\
\text { of projected } \\
\text { Local Revenue } \\
+ \text { if applicable, } \\
50 \% \text { of the net } \\
\text { AR for new line } \\
\text { of business } \\
\text { projects less } \\
47.5 \% \text { of the } \\
\text { Joint } \\
\text { Contribution } \\
\text { Amount }\end{array}$ & $\begin{array}{l}\text { Soft cap with } \\
\text { many excep- } \\
\text { tions. Players } \\
\text { receive between } \\
49-51 \% \text { of } \\
\text { defined rev- } \\
\text { enues. Team } \\
\text { minimum is } \\
80 \% \text { of cap in } \\
2011-12,85 \% \\
\text { in } 2012-13 \text {, } \\
90 \% \text { thereafter. } \\
\text { Level in } 2011- \\
12 \text { is same as } \\
2010-11 \text { ( } \$ 58 \\
\text { million), but } \\
\text { pro-rated for } \\
\text { shortened sea- } \\
\text { son. }\end{array}$ & $\begin{array}{l}\text { Players will } \\
\text { receive } 54-57 \% \\
\text { of defined rev- } \\
\text { enues (escalat- } \\
\text { ing as league } \\
\text { revenues rise). } \\
\$ 64.3 \text { million in } \\
2011-12 \text {. }\end{array}$ \\
\hline $\begin{array}{l}\text { Individual Player } \\
\text { Salary Minimum } \\
\text { \& Maximum }\end{array}$ & $\begin{array}{l}\text { Minimum is } \\
\$ 480,000 \text { in } \\
2012 . \text { There is } \\
\text { no maximum. }\end{array}$ & $\begin{array}{l}\text { Minimum } \\
\text { ranges from } \\
\$ 375,000 \text { for } \\
\text { rookies to } \\
\$ 910,000 \text { for } \\
\text { veterans with } \\
10+\text { years of } \\
\text { service for } 2011 \text {. } \\
\text { Levels increase } \\
\text { by } \$ 15,000 \text { each } \\
\text { year. }\end{array}$ & $\begin{array}{l}\text { Minimum } \\
\text { ranges from } \\
\$ 473,604 \text { for } \\
\text { rookies to } \\
\$ 1,352,181 \text { for } \\
\text { veterans with } \\
10+\text { years of } \\
\text { service for } \\
2010-11 \text {. Players } \\
\text { can sign for up } \\
\text { to } 35 \% \text { of team } \\
\text { salary cap or } \\
105 \% \text { of previ- } \\
\text { ous year's } \\
\text { salary, whichev- } \\
\text { er is higher. }\end{array}$ & $\begin{array}{l}\$ 525,000 \text { mini- } \\
\text { mum in } 2011- \\
12 . \text { No player } \\
\text { can earn more } \\
\text { than } 20 \% \text { of } \\
\text { team salary cap. }\end{array}$ \\
\hline
\end{tabular}


Table 7: Collective Bargaining Agreements Across Leagues, 2012, continued

\begin{tabular}{|c|c|c|c|c|}
\hline CBA Component & MLB & NFL & NBA & NHL \\
\hline Free Agency & $\begin{array}{l}\text { Players with } 6 \\
\text { or more years } \\
\text { of service (in } \\
40 \text {-man roster) } \\
\text { are eligible for } \\
\text { free agency. } \\
\text { Draft pick com- } \\
\text { pensation for } \\
\text { previous club. }\end{array}$ & $\begin{array}{l}\text { Players with } 4 \\
\text { or more } \\
\text { accrued seasons } \\
\text { become unre- } \\
\text { stricted free } \\
\text { agents at end of } \\
\text { their contract. } \\
\text { Players with } 3 \\
\text { accrued seasons } \\
\text { can be retained } \\
\text { as restricted free } \\
\text { agents (draft } \\
\text { pick compensa- } \\
\text { tion for prior } \\
\text { club). }\end{array}$ & $\begin{array}{l}\text { Players are free } \\
\text { agents at termi- } \\
\text { nation of con- } \\
\text { tract. Certain } \\
\text { players are sub- } \\
\text { ject to restricted } \\
\text { free agency. No } \\
\text { compensation } \\
\text { for teams that } \\
\text { lose free agents. }\end{array}$ & $\begin{array}{l}\text { Players } 27 \text { years } \\
\text { or older (with } 4 \\
\text { accrued sea- } \\
\text { sons), or players } \\
\text { with } 7 \text { accrued } \\
\text { seasons will be } \\
\text { unrestricted } \\
\text { free agents. } \\
\text { Restricted FAs } \\
\text { are subject to } \\
\text { right of first } \\
\text { refusal and } \\
\text { draft pick com- } \\
\text { pensation for } \\
\text { prior club. }\end{array}$ \\
\hline Salary Arbitration & $\begin{array}{l}\text { Top } 22 \% \text { of } \\
\text { players with } \\
\text { two years of } \\
\text { service are eligi- } \\
\text { ble for salary } \\
\text { arbitration }\end{array}$ & None & None & $\begin{array}{l}\text { After } 4 \text { years in } \\
\text { the league, play- } \\
\text { ers are eligible } \\
\text { for salary arbi- } \\
\text { tration. }\end{array}$ \\
\hline Draft Restrictions & $\begin{array}{l}\text { Reverse-order } \\
\text { draft plus addi- } \\
\text { tional CB } \\
\text { enhancements. } \\
\text { International } \\
\text { players are free } \\
\text { agents. Teams } \\
\text { have a total sum } \\
\text { of money for } \\
\text { signing bonuses }\end{array}$ & $\begin{array}{l}\text { Seven rounds } \\
\text { (reverse order } \\
\text { of finish) plus } \\
\text { compensatory } \\
\text { picks at end of } \\
\text { rounds 3-7 } \\
\text { based on unre- } \\
\text { stricted free } \\
\text { agents lost in } \\
\text { prior year. } \\
\text { Eligibility } \\
\text { requires being } 3 \\
\text { years removed } \\
\text { from high } \\
\text { school. }\end{array}$ & $\begin{array}{l}\text { Two rounds; } \\
\text { same order in } \\
\text { both rounds. } \\
\text { No compensa- } \\
\text { tory picks. } \\
\text { Extensive eligi- } \\
\text { bility rules. }\end{array}$ & $\begin{array}{l}\text { Reverse-order } \\
\text { weighted draft. } \\
\text { Free agent and } \\
\text { other draft pick } \\
\text { compensation. } \\
\text { Min. } 18 \text { years of } \\
\text { age. }\end{array}$ \\
\hline Debt Service Rule & $\begin{array}{l}\text { Maximum debt } \\
\text { is } 8^{\star} \text { EBITDA } \\
\left(12^{\star} \text { EBITDA }\right. \\
\text { for teams with } \\
\text { new stadiums })\end{array}$ & $\begin{array}{l}\text { General debt } \\
\text { ceiling of } \$ 150 \\
\text { million with } \\
\text { waivers possi- } \\
\text { ble. Separate } \\
\text { rules for G-3 } \\
\text { loan. }\end{array}$ & None & None \\
\hline
\end{tabular}


Table 7: Collective Bargaining Agreements Across Leagues, 2012, continued

\begin{tabular}{|c|c|c|c|c|}
\hline CBA Component & MLB & NFL & NBA & NHL \\
\hline $\begin{array}{l}\text { Rookie } \\
\text { Compensation }\end{array}$ & $\begin{array}{l}\text { No maximum } \\
\text { for rookie MLB } \\
\text { players }\end{array}$ & $\begin{array}{l}\text { Each team has a } \\
\text { Maximum } 1^{\text {st }} \\
\text { year allotment } \\
\text { based on draft } \\
\text { slots and each } \\
\text { player has a } \\
\text { minimum } 1^{\text {st }} \\
\text { year comp so } \\
\text { contracts must } \\
\text { be negotiated } \\
\text { within set } \\
\text { parameters. } 5 \\
\text { year contracts } \\
\text { for } 1^{\text {st }} \text { round, } 4 \\
\text { years for } 2^{\text {nd }} \text { - } \\
7^{\text {th }} \text { rounds, } 3 \\
\text { years for } \\
\text { undrafted. }\end{array}$ & $\begin{array}{l}\text { Rookie salary } \\
\text { scale in place } \\
\text { for } 1^{\text {st }} \text { round } \\
\text { picks (covering } \\
\text { first } 2-4 \text { years). } \\
\text { Cap for first } \\
\text { pick is } \$ 4.3 \text { mil- } \\
\text { lion in } 2011-12 \\
\text { (pro-rated). }\end{array}$ & $\begin{array}{l}\$ 925,000 \text { plus } \\
\text { substantial } \\
\text { bonuses. } \\
\text { Younger players } \\
\text { stay under these } \\
\text { Entry Level } \\
\text { contracts for } \\
\text { longer before } \\
\text { becoming arbi- } \\
\text { tration eligible. }\end{array}$ \\
\hline Squad Size & $\begin{array}{l}25 \text { players until } \\
\text { Sept. } 1 \text {, then } 40 \\
\text { players }\end{array}$ & $\begin{array}{l}53 \text { in season ( } 46 \\
\text { active for } \\
\text { games), } 80 \text { in } \\
\text { off-season }\end{array}$ & $\begin{array}{l}15 \text { maximum, } \\
13 \text { minimum. }\end{array}$ & $\begin{array}{l}23 \text { players on } \\
\text { active roster ( } 20 \\
\text { eligible to play } \\
\text { per game) }\end{array}$ \\
\hline $\begin{array}{l}\text { Guaranteed } \\
\text { Contracts }\end{array}$ & $\begin{array}{l}100 \% \text { of } \\
\text { remaining value } \\
\text { is guaranteed }\end{array}$ & $\begin{array}{l}\text { Negotiated. } \\
\text { Outside of } 1^{\text {st }} \\
\text { round draft } \\
\text { picks contracts } \\
\text { are almost } \\
\text { never fully } \\
\text { guaranteed. }\end{array}$ & $\begin{array}{l}\text { Certain salary } \\
\text { must be guar- } \\
\text { anteed. Rest is a } \\
\text { matter of nego- } \\
\text { tiation. In prac- } \\
\text { tice, the } \\
\text { majority of } \\
\text { NBA contracts } \\
\text { are fully guar- } \\
\text { anteed. }\end{array}$ & $\begin{array}{l}1 / 3 \text { of remain- } \\
\text { ing salary, if less } \\
\text { than } 28 \text { years } \\
\text { old; } 2 / 3 \text { of } \\
\text { remaining value } \\
\text { if over } 28 \text {. }\end{array}$ \\
\hline
\end{tabular}

and provide more competitive balance to MLB, an area that has received a great deal of attention from owners, media, and fans over the past decade.

Another area of discussion in recent years for MLB has been the acquisition of international talent. Historically, players coming from nations such as Taiwan and Japan have not been included in the June Amateur Draft. Once eligible to play in MLB, they have been considered free agents, and this has led to bidding wars amongst teams for talented international players such as Daisuke Matsuzaka (Dice-K) and Yu Darvish. In the case of Dice-K, the Boston Red Sox paid \$51 million to his Japanese professional team for the right to negotiate a contract with him over a 30-day period. The Red Sox eventually gave Dice-K a six-year, \$52 million contract. So, ultimately, it cost Boston over $\$ 100$ million to acquire Matsuzaka. Due to these high contract amounts for international star players, most of them have signed with high-revenue, big-market teams such as the Red Sox, Yankees, Cubs, and Dodgers. Many small-market teams have been highly critical of this system and have demanded changes. 
Table 7: Collective Bargaining Agreements Across Leagues, 2012, continued

\begin{tabular}{|c|c|c|c|c|}
\hline CBA Component & MLB & NFL & NBA & NHL \\
\hline Drug Testing & $\begin{array}{l}\text { PES testing } \\
\text { (incl. HGH) } \\
\text { throughout } \\
2012 \text { season for } \\
\text { reasonable } \\
\text { cause. First } \\
\text { offense is 50- } \\
\text { game suspen- } \\
\text { sion. }\end{array}$ & $\begin{array}{l}\text { Increasing dis- } \\
\text { cipline for } \\
\text { failed or diluted } \\
\text { tests. More fre- } \\
\text { quent tests for } \\
\text { those who have } \\
\text { failed a prior } \\
\text { test. }\end{array}$ & $\begin{array}{l}\text { Players subject } \\
\text { to random test- } \\
\text { ing during the } \\
\text { pre-season peri- } \\
\text { od (no HGH), } \\
\text { rookies are sub- } \\
\text { ject to random } \\
\text { testing three } \\
\text { times during } \\
\text { the regular sea- } \\
\text { son, and all } \\
\text { players are sub- } \\
\text { ject to testing } \\
\text { for reasonable } \\
\text { causes at any } \\
\text { time. Steroids } \\
\text { were added to } \\
\text { the list of } \\
\text { banned sub- } \\
\text { stances in } 1999 \text {. } \\
\text { First offense is a } \\
10 \text {-game sus- } \\
\text { pension. }\end{array}$ & $\begin{array}{l}\text { PES testing } \\
\text { twice per year, } \\
\text { with } 20 \text {-game } \\
\text { suspension for } \\
\text { first offense. }\end{array}$ \\
\hline $\begin{array}{l}\text { Head Injury } \\
\text { Program }\end{array}$ & $\begin{array}{l}\text { Improved upon } \\
2011 \text { concus- } \\
\text { sion policy } \\
\text { (specifics not } \\
\text { yet available) }\end{array}$ & $\begin{array}{l}\text { Player with } \\
\text { concussion } \\
\text { symptoms is } \\
\text { removed for } \\
\text { remainder of } \\
\text { game and can- } \\
\text { not return to } \\
\text { practice or play } \\
\text { until he passes } \\
\text { strict testing } \\
\text { requirements }\end{array}$ & $\begin{array}{l}\text { Players diag- } \\
\text { nosed with con- } \\
\text { cussion go } \\
\text { through series } \\
\text { of escalating } \\
\text { tests. Then, just } \\
\text { remain asymp- } \\
\text { tomatic for } 24 \\
\text { hours. May miss } \\
\text { days or weeks. }\end{array}$ & $\begin{array}{l}\text { Player removed } \\
\text { from game and } \\
\text { tested after each } \\
\text { possible inci- } \\
\text { dent. }\end{array}$ \\
\hline
\end{tabular}

Note: CB is competitive balance; PES is Performance Enhancing Substance.

Sources: Larry Coon at cbafaq.com provided some of the information for the NBA; Brian Hampton, Director of Football Administration, San Francisco 49ers, provided some of the information for the NFL; CBAs for each league.

The 2011 CBA is the first to formally address the amount of money spent on international talent. Similar to the Amateur Draft Signing Bonus Pool, a signing bonus pool has been established for international talent. For the post-2012 season signing period, each team will be assigned an equal signing bonus pool amount. In later seasons, the amount for each team will be determined based on winning percentage in the previous season. The team with the lowest winning percentage will have the largest pool amount. A team will pay a tax, ranging from $75 \%$ to $100 \%$, on the amount of overage over their designated signing pool amount that the team spends to acquire international talent (“Summary," 2011). 
Since the 2002 CBA, there has been a debt service rule in MLB in effect to curb the accrual of high levels of debt by team owners. Under the old agreement, a team's debt was limited to 10 times their level of earnings before interest, taxes, depreciation, and amortization (EBITDA). One exception to this rule was that teams with new or renovated ballparks could have debt up to 15 times their EBITDA. The $2011 \mathrm{CBA}$ reduces these levels to eight times EBITDA for clubs, and 12 times EBITDA for clubs in new or renovated ballparks.

With respect to the players' benefit and pension plans, the new CBA continues to give the players the maximum pension benefit that is allowable under IRS rules. Currently, the club owners make an annual contribution of approximately $\$ 184.5$ million to the players' pension fund. Some minor improvements to the pension and life insurance benefits of certain classes of retired players and their widows were made, while the waiting period for life insurance and disability insurance was eliminated for some active players. Access to health insurance has also been improved for international players and their families ("Summary," 2011).

Several changes have been made under the new CBA with respect to the safety and health of players, coaches, and managers. First, the use of smokeless tobacco, an accepted product in baseball for decades, will be prohibited during televised interviews and team appearances. Additionally, any time that fans are permitted into the ballpark, all containers for smokeless tobacco must be concealed. Violators are subject to discipline and both parties agreed to participate in educational programs and community outreach to publicize the danger of smokeless tobacco products. Both parties also agreed to a program of mandatory evaluation by a trained professional for players who are suspected of alcohol use problems. This includes players who are arrested for driving while intoxicated and for players arrested for crimes involving the use of violence ("Summary," 2011).

Lastly, the drug testing program that was enacted in 2008 after the steroid scandal will remain in effect. One new component of the program is that beginning with the 2012 Spring Training, all players are given a blood test for human growth hormone $(\mathrm{HGH})$. Additionally, players may undergo random $\mathrm{HGH}$ tests at any time during the year if reasonable cause exists. Beginning in 2013, all players will be subject to random, unannounced testing for HGH.

\section{Comparison of 2011 CBA Negotiations in MLB to NFL, NBA, and NHL}

A key result of the new CBAs in football, basketball, and baseball, and the NHL's current CBA that ends in 2012, is the convergence of player pay toward $50 \%$ of total league revenues. NBA players' salaries came down in their recent CBA from $57 \%$ to a range between $49-51 \%$ of basketball-related income (see Berri, pp. 158-175 of this journal issue). The salary cap in the NFL went from 57\% of total revenue (TR) in 2006 to the current level, which is capped at 48\% in 2012 (Zimbalist, 2010; Singer-Vine, 2011; see Quinn, pp. 141-157 of this journal issue). Yet, since the cap allows for exceptions, Zimbalist calculated that NFL players actually received about $58.4 \%$ of TR in 2006. In the NHL, players currently receive between $54-57 \%$ of hockey-related revenue. ${ }^{1}$ See Table 7 for a comparison of key provisions of the Big 4's CBAs and side agreements. While a revenue split of $50 \%$ should not be a magical number, Billy Hunter of the NBPA noted in public that he thought the players deserved more than 
the owners simply because they were the ones playing the game and generating the revenues (Beck, 2011). In that context, 50\% is very meaningful.

In MLB, the percentage of total revenues that players receive has been more volatile over the years, likely because there is no cap to tether player salaries directly to league revenue. From a peak of $67 \%$ in 2002, it went down to about $51 \%$ in 2007 . Zimbalist (2010) noted that over $6 \%$ of MLB's revenues go toward paying minor league players, and some of the cost of acquiring players in MLB from overseas goes to the overseas club and not to the player. For example, about half of Matsuzaka's \$103 million cost went to his former club in Japan. Also, while no salary cap exists in MLB as it does in the NFL, NBA, and NHL, the luxury tax and revenue sharing plan act as a drag on players' salaries. The data described above bear this out, as there has been an increase in revenue sharing and luxury taxes paid over the past decade in MLB. This may also be true of the provisions for draft pick compensation and draft signing pools under the new CBA.

Interestingly, the owners offered a team payroll floor of about $\$ 40$ million in the 2002 bargaining session as an alternative to the enhanced revenue sharing system. The goal was to help improve competitive balance, especially since it is possible for revenue sharing recipients to avoid using the revenue sharing money to directly improve the quality of play on the field, but a team salary minimum could not be avoided. The players rejected this option because they did not want it to be the first step toward a team salary cap, and the $\$ 40$ million was close to the lowest team payrolls at the time anyway (Zimbalist, 2010).

How did MLB avoid the pitfalls of lockouts and lawsuits that plagued the NFL and NBA negotiations? Before answering that question, a result of less contention is less media coverage. Evidence showing that the MLB negotiations were either less contentious or less public, or both, comes from an examination of media coverage. A search on the New York Times website for the six months leading up to the deals' being reached for the NFL, NBA, and MLB found 82 articles for the NFL, 13 for the NBA, and two for MLB. The following search terms were used: "NFL collective bargaining," "NBA collective bargaining," and "MLB collective bargaining." ${ }^{2}$ On Google.com, a search using the same timeframe and search terms yielded 72,200 hits for the NBA; 70,800 for the NBA; and 40,800 for MLB.

Revenues in MLB have been growing substantially, up 30\% since the last CBA was negotiated in 2006, partially due to the aggressive growth pursued by MLB Advanced Media utilizing non-traditional sports league revenue streams. This growth has undoubtedly helped make the negotiations in MLB less antagonistic. Second, MLB has had the longest history of problematic CBA negotiations, with the result being missed games and post-season cancellation. As noted by Matheson (2006), this has had a true negative and lasting impact on attendance. Both sides seem to realize this and worked hard to avoid a work stoppage in 2011. Third, the purposeful act of staying out of the media has made the controversies within the negotiations private. The leaders have been successful in keeping their respective constituents quiet. Fourth, the absence of a salary cap in MLB means that a team, if it desires, can spend as much as it wants, subject to a luxury tax, on players' compensation. Thus, the amount that players will receive from a new $\mathrm{CBA}$ is uncertain and that uncertainty may actually help lead to 
agreement. In the other leagues, a salary cap is the key negotiating point because it is directly tied to player pay, almost dollar for dollar.

How do the CBAs differ across the major professional North American sports leagues? As noted by Vrooman (2009): "As recent power conflicts have been resolved, the various collective bargaining solutions are becoming remarkably similar.” MLB's deal is the shortest at five years, while the NFL's is the longest. With a hard salary cap in place, the NFL can achieve more certainty in terms of expenses versus revenues regardless of if the league grows quickly over the next decade. In MLB, since player payroll is untethered from revenues, one of the sides may feel that it is losing a lot after half of a decade. The NFL still shares the most revenue due to the substantially larger national media deal, but both MLB and the NBA have increased their revenue sharing and specifically push money down to lower-revenue teams as opposed to equally sharing a larger sum of money. Also, MLB and the NBA have a luxury tax in place that punishes teams spending above a certain level: the soft salary cap in the NBA and luxury tax payroll thresholds in MLB.

As mentioned elsewhere, MLB stands alone with no salary cap and a high luxury tax threshold; it will be $\$ 178$ million in 2012. However, the increased revenue sharing should lower the incentive to pay more for players. The tightening of the enforcement of having recipient teams spend that money will help offset those incentives and get lower-revenue teams to spend more on players instead of pocketing the money. On balance, MLB still has the most restrictive free agency rules at six years of MLB service. The NHL is between four and seven years of service, depending on the age of the player, with both the NFL and NBA granting free agency to players with three to four years in their respective league when their contract expires. However, MLB does have salary arbitration available for players with two to three years of service. In comparison, the NHL grants salary arbitration after four years of service. In general, arbitration raises MLB salaries to levels between the reserve clause and free agent pay, all else equal.

Interesting changes to MLB's draft policies have made the draft more beneficial to lower-revenue teams by providing more picks and lowering the cost of signing bonuses. Given that drafted players in baseball do not enter MLB immediately, but play in the minors, the impact of the draft on MLB club team quality has always been less direct and certain. The new rules help compensate for that lack of parity due to the draft, but still not as much as reverse-order drafts in the other sports, where the players immediately play in the top league.

MLB still does not have rookie pay caps, unlike the other leagues, but has capped signing bonuses, and the players stay under the reserve clause longer than in other leagues. One could imagine rookie salary caps in MLB as a future negotiating point for MLB owners and current players given that rookies will not be at the bargaining table to fight for their own rights. MLB still has more pay guaranteed, by far, than the other leagues with the NHL next and the NFL last.

Collective bargaining in MLB is atypical when compared to union negotiations in other non-sport industries. The next section will address some of these structural differences, such as the relative leverage of both sides, typical negotiating timetables, and bargaining techniques.

\section{Comparison of MLB Bargaining Context to Non-Sports Industries}


Unlike the recent bargaining in the NBA and NFL, MLB's bargaining for the 2011 deal was very quiet. As stated earlier, this was also true of the 2006 MLB bargaining process. There may be several reasons for the relative lack of media attention to both deals, but the most important is probably the moratoriums that were placed on the two sides by both Commissioner Selig and the head of the MLBPA, Donald Fehr in 2006 and Michael Weiner in 2011. This kept the bargaining at the table and out of the headlines. Given the public nature of bargaining in the NFL and NBA, and the relatively calm MLB negotiations of 2006, it is not clear that the economic recession was actually a factor in MLB's negotiations.

Historically, what has made labor relations in MLB so turbulent? Covington (2003) noted that three bodies of law play a role in MLB labor relations. First, antitrust laws have been available to players since the 1998 passage of the Curt Flood Act, which repealed the antitrust exemption solely as it relates to owner/player relations. Second, the National Labor Relations Act (NLRA) governs collective bargaining between the players' union and the owners. However, it often lacks the teeth to be able to force quick solutions. Instead, both sides negotiate in circles until a crisis develops, such as the cancellation of regular-season or post-season games. After Brown v. Pro Football, Inc. (1996), players can only pursue relief via the antitrust laws if they choose to not pursue relief through formal collective bargaining. In other words, they have to choose one or the other. Hence, we recently saw the decision by NBA players to disband their union and file an antitrust lawsuit. Third, the Taft-Hartley Act (1947) pushes for arbitration to resolve disputes, which has been used in professional baseball to resolve issues. Examples of this are the Messersmith and McNally arbitrations that opened the door to free agency.

There are several factors related to the structure of the players' union that affect the bargaining process. For example, the MLBPA cannot bargain for those players who are not in the union. However, as Gould (2011) notes, the NLRA defines "employee" in a broad enough sense to allow the MLB CBA to create draft rules, for instance, which involve amateur players. The MLBPA is also exclusive and a "closed shop" in that it represents all players and all players must join the union. Perhaps the biggest historical impediment to successful labor union negotiations has been the lack of trust by the players with respect to the amount that the owners could afford to pay. The players have asked the courts to force the teams to open their books, and the courts have continually denied this request (Silverman v. MLBPRC, 1981). In 2011, the NFL Players Association was only able to get minimal financial data, mostly on the revenue side, from the NFL owners during their negotiations.

\section{Comparison to Traditional American Unions}

Traditional labor/management bargaining situations in the U.S. involved unskilled or low-skilled workers, with more highly skilled workers unionizing at a later date. Typically, workers attempted to achieve control over their work conditions including hours, pay, safety, and tasks (Rainsberger, 2009). As stated previously, in its early days the MLBPA was primarily focused on issues related to pension funding, increasing the minimum salary, bringing an end to the reserve clause, and improving work conditions. However, over the decades, the MLBPA expanded its economic and political interests. For example, the MLBPA was involved in the formation and passing of the 
Curt Flood Act in 1998, which put MLB players in the same position as athletes in other sports with respect to their antitrust rights. The goals of the MLBPA have changed over time. Presently, their goals are primarily related to compensation and risk minimization through the protection of guaranteed contracts. Similar to other American industries over the past century, MLBPA has achieved success on issues such as hours worked and safety issues, and is now focused on the nuances of retirement benefits and total compensation.

Like most bargaining situations, the relative power of the MLBPA and MLB owners determines the outcome, subject to the NLRA and antitrust laws. The necessary conditions for the MLBPA to advance its causes, as with most labor unions, are favorable product market factors, labor market factors, bargaining structure, and the bargaining climate.

The key product market factor that affects CBA outcomes is the employer's ability to pay (Rainsberger, 2009). This has been a contentious issue for most sports leagues, MLB included. There has been a lack of trust between the players and owners regarding economic profitability and franchise valuations. MLB's revenues have grown rapidly over the past decade, and since the 2006 agreement was signed, revenues have grown an estimated $30 \%$ as reported annually by Forbes. For example, MLB's intellectual property arm, MLB Advanced Media, is reportedly worth $\$ 5$ billion (Carter, 2011).

Productivity increases are usually another key item in bargaining (Rainsberger, 2009). In MLB, productivity can be addressed in several ways. More games can be played, although the number of games during the regular season has not been a bargaining issue in MLB, unlike the NFL. There are some exceptions, like adding more playoff teams, so that more postseason games are played. This was witnessed with the expansion of the playoffs through the addition of two wild card teams as part of the 2011 CBA. Alternatively, productivity can be measured by the number of units sold per game (e.g., attendance, viewership, or merchandise), which has risen over time. Player pay loosely tracks player productivity, measured as marginal revenue product, notwithstanding structural institutions in place like the reserve clause. At a minimum, the MLBPA wants player compensation to equal the increases in revenue that occur because of increases in MRP. Owners may claim, however, that much of the increase in demand is due to new stadiums, better marketing, better pricing, new licensing opportunities, and new media outlets.

With respect to labor market factors, the MLBPA may be viewed as both a craft-based union such as the United Brotherhood of Carpenters and Joiners of America and an industrial union like the United Auto Workers. In other industries, the bargaining power of such a narrow union might be relatively low because of the substitutability of similar craft workers in another industry. However, MLB players are highly skilled and unique; therefore, they are very hard to replace without a loss of productivity.

The MLBPA is also a closed shop; this means that players are automatically part of the bargaining unit and there is no competitive union. Occasionally, star athletes have opted out of certain aspects of the MLBPA. For instance, in 2003, Barry Bonds chose to not participate in the group licensing agreement managed by the MLBPA. He preferred to sign his own licensing deals for products such as video games and trading cards instead of automatically being included in the group licensing deal. However, these cases are extremely rare. 
Another factor that affects owner-union relations in MLB is the bargaining structure that is in place. Most collective bargaining in the U.S. occurs between firms in an oligopolistic or competitive structure with the workers organized in the form of unions. While the union may have more monopoly power than the firms have market power, union strikes are financially painful for union members, so it can be difficult for unions to commit to lengthy strikes. Professional baseball is a bilateral monopoly. MLB has no competitors vying for professional baseball talent, notwithstanding a few MLB players who go overseas to play in countries like Japan or Korea, and the MLBPA is composed of uniquely skilled professionals with little, if any, external competition. Given these characteristics and the overall popularity of MLB globally, both sides have benefitted financially, with MLB generating in excess of $\$ 7$ billion in annual revenue and the average MLB player making over $\$ 3.3$ million a year. There are very few unions, if any, outside of sport where union members earn that type of average salary. Due to this, both players and owners can withstand, at extreme financial loss, lengthy work stoppages. Compared with other sports leagues, MLB players have relatively long careers and have, at times, been willing to forego millions of dollars in current earnings in exchange for higher future earnings and advancements in other areas such as pensions, free agency, and salary arbitration.

The 2011 round of collective bargaining in MLB was notable for having been finalized over three months prior to the beginning of spring training for next season. In other words, it did not seem to follow the classic bargaining pattern of early, middle, and crisis/closing bargaining periods. One reason for a relatively easy agreement process was that revenues have been rising quickly in MLB. Over the past decade, league-wide revenues have more than doubled. It appears that both sides recognized that the fan base was very sensitive to millionaires and billionaires arguing over how to divide tens of billions of dollars. Two other factors that contributed to the ease of negotiations were the weak state of the global economy and the nasty public nature of the negotiations in the NFL and the NBA.

To understand how collective bargaining progresses, it is important to account for the bargaining climate (Rainsberger, 2009). In the early years of the MLBPA, it followed other young unions in negotiating for rights like union recognition; a formal grievance process; protection against unjust disciplinary action; and contract term, expiration, and renegotiation provisions. However, even in its infancy MLBPA addressed economic goals. Currently, the union is interested in areas such as minimum salaries, health/pension benefits, revenue sharing, and luxury taxes. Another area that is of high interest to the MLBPA is the mandatory testing procedures for PEDs and the accompanying penalty system for failed tests. Management is also interested in compensation issues along with competitive balance. Luxury taxes, revenue sharing, and a salary cap that is desired by most owners are all tools related to compensation and parity. Owners are also interested in retaining all rights not specifically bargained over like the schedule of games and the number of teams.

Finally, bargaining techniques are a factor in the success of collective bargaining (Rainsberger, 2009). Typical ground rules include aspects such as the time, place, and frequency of bargaining sessions; methods of communication between sessions; an understanding that all agreements are contingent on the entire package being agreed upon; restrictions on external communications; and the order in which topics will be 
bargained. It is imperative in bargaining that each side be unified in its approach at the table. This has been a real problem over the years, especially in the mid-1990s, between large- and small-market clubs on the owners' side, but less so between journeymen and star players on the players' side. Without a salary cap, there are fewer direct dollarfor-dollar tradeoffs amongst players' salaries. This is in contrast to other leagues such as the NBA where, for instance, Michael Jordan allegedly attempted to decertify the players' union (Bradley, n.d.; Quirk \& Fort, 1999).

\section{The Future}

In the next 5-10 years, MLB should see improved competitive balance because revenue- sharing recipients will find it more difficult to avoid using their additional funds to improve their on-the-field product, and large market clubs will be exempt from being recipients of revenue-sharing money. The elephant in the room will continue to be the salary cap, but the competitive balance argument may carry less weight if the other measures improve competitive balance.

Both owners and players recognize that they need to grow their fan base, both domestically and internationally. The Industry Growth Fund coming from luxury taxes will help, as will the growth of the Australian Baseball League and domestic leagues in other countries. The World Baseball Classic should help speed up the growth of baseball worldwide, which will position MLB as the premier league for a new generation of fans (Nagel, Brown, Rascher, \& McEvoy, 2010). These issues, while relatively uncontroversial, will be a focus in future CBAs.

Very soon, all international players will become incorporated into the amateur draft (partially because they will not be at the table to represent their interests). Additionally, issues surrounding performance enhancing drugs and how to prevent their use will grow in importance in the next decade. Similarly, new research on head injuries will play a role in MLB during the future, with some aspects negotiated at the bargaining table.

Finally, the major North American sports leagues will continue to converge in terms of the structure of the relationship between the owners and the players, with MLB players continuing to have the most relative leverage of the various leagues because of the average length of players' careers.

\section{References}

Beck, H. (2011, November 4). 50 N.B.A. players considering dissolution of union. The New York Times, p. B10.

Bloom, H. (2006a, October 24). The good news a new MLB labor accord, the bad news a new MLB labor accord II. SportsBusiness News. Retrieved from http://www.sports businessnews.com/_news/news_352522.php

Bloom, B. (2006b, October 25). MLB, union announce a new deal. MLB.com. Retrieved from http://mlb.mlb.com/news/article.jsp?ymd=20061024\&content_id=1722211\&fext=.jsp\&c_i $\mathrm{d}=\mathrm{mlb}$

Bradley, R. (n.d.). Labor pains nothing new to the NBA. Retrieved from http://www.apbr.org/labor.html

Brown v. Pro Football, Inc., 518 U.S. 231, 236 (1996).

Carter, D. (2010). Money games: profiting from the convergence of sports and entertainment. Stanford, CA: Stanford Business Books. 
Coates, D., \& Harrison, T. (2005). Baseball strikes and the demand for attendance. Journal of Sports Economics 6(3), 282-302.

Covington, R. (2003). (How much) is the law to blame for baseball's turbulent labor relations? Journal of Sports Economics 4(4), 356-361.

Dosh, K. (2007, June 28). Does revenue sharing in MLB foster competitive balance? Retrieved on from http://mvn.com/mlb-braves/2007/06/28/does-revenue-sharing-in-mlbfoster-competitive-balance/

Gould, W. (2011). Bargaining with baseball. Jefferson, NC: McFarland \& Company, Inc.

Hakes, J. \& Turner, C. (2011). Pay, productivity and aging in Major League Baseball. Journal of Productivity Analysis, 35(1), pp. 61-74.

History of the Major League Baseball Players Association. (2012) . MLBPlayers.com. Retrieved from http://mlbplayers.mlb.com/pa/info/history.jsp

Kovacevic, D. (2005, May 1). The debate about the Pirates' demise always comes back to team payroll: In the age of revenue sharing and television contracts, how much are the Pirates making and what are they doing with the profits? Pittsburgh Post-Gazette, p. C-1.

Krautmann, A., von Allmen, P., \& Berri, D. (2009). The underpayment of restricted players in North American Sports leagues. International Journal of Sport Finance, 4, 161-175.

Matheson, V. (2006). The effects of labour strikes on consumer demand in professional sports: revisited. Applied Economics 38(10), pp. 1173-1179.

Maxcy, J. (2009). Progressive revenue sharing in Major League Baseball: The effect on player transfers and talent distribution. Review of Industrial Organization, 35, 275-297.

Nagel, M., Brown, M., Rascher, D., \& McEvoy, C. (2010). Expanding global consumer market for American sports: The World Baseball Classic. In C. Santo \& G. Mildner (Eds.), Sport and public policy (pp. 215-229). Champaign, IL: Human Kinetics.

Noll, R. (2003). The economics of baseball contraction. Journal of Sports Economics, 4(4), 367-388.

O'Reilly, N. (2011). Experimental design methods in sport management research: The playoff safety bias. Journal of Sport Management, 25(3), pp. 217-228.

Quirk, J., \& Fort, R. (1999). Hard ball. Princeton, NJ: Princeton University Press.

Rainsberger, P. (2009, April 29). Historical models of collective bargaining in the U.S. University of Missouri Extension. Retrieved from http://labored.missouri.edu/research/historical.htm

Schmidt, M., \& Berri, D. (2002). The impact of the 1981 and 1994-1995 strikes and major league baseball attendance: A time-series analysis. Applied Economics, 34, 471-478.

Schmidt, M., \& Berri, D. (2004). The impact of labor strikes on consumer demand: An application to professional sports. American Economic Review, 94, 344-357.

Silverman v. Major League Baseball Player Relations Comm., 516 F.Supp. 588 (S.D.N.Y. 1981).

Singer-Vine, J. (2011, July 21). Did the NFL players get a raw deal? Slate. Retrieved from http://www.slate.com/articles/news_and_politics/explainer/2011/07/did_the_nfl_players_g et_a_raw_deal.html

Snel, A. (2005, April 20). As Rays whiff, front office scores. Tampa Bay Online. Retrieved from http://news.tbo.com

Staudohar, P. D. (2000). Diamond mines: Baseball \& labor. Syracuse, NY: Syracuse University Press.

Summary of Major League Baseball Players Association - Major League Baseball Agreement. (2011). Retrieved from http://mlb.mlb.com/mlb/downloads/2011_CBA.pdf

Vrooman, J. (2009). Theory of the perfect game: Competitive balance in monopoly spots leagues. Review of Industrial Organization, 34(1), pp. 5-44.

Weir, T. (2002, October 16). New revenue likely won't help payrolls. USA Today. Retrieved from http://www.usatoday. com 
Zimbalist, A. (2003a). Labor relations in Major League Baseball. Journal of Sports Economics, 4(4), pp. 332-355.

Zimbalist, A. S. (2003b) May the best team win: Baseball economics and public policy. Washington, D.C: Brookings Institution.

Zimbalist, A. (2010). Reflections on salary shares and salary caps. Journal of Sports Economics, 11(1), pp. 17-28.

\section{Endnotes}

${ }^{1}$ The definitions of basketball-related income, hockey-related revenue, and total revenue take up dozens of pages in the respective CBAs, but over time have expanded to include more revenue streams.

${ }^{2}$ The NFL deal was agreed upon on July 21, 2011; the NBA deal was reached on November 26, 2011; and MLB's deal was reached on November 17, 2011. 
Reproduced with permission of the copyright owner. Further reproduction prohibited without permission. 